\title{
PENGARUH CAPITAL STRUCTURE DAN WORKING CAPITAL MANAGEMENT TERHADAP PROFITABILITAS
}

\author{
Ratu Dintha IZFS \\ Universitas Pendidikan Indonesia \\ ratudinthaizfs@gmail.com \\ Dr. H. Ahim Surachim \\ Universitas Pendidikan Indonesia \\ ahimsurachim@upi.edu
}

\begin{abstract}
ABSTRAK
This research was intended to know the impact of capital structure and working capital management on the profitability of PT. Indosat Tbk in the period of 2005-2014. This research applied descriptive and verification method concluded in time series design. The statistic analysis that was used in this study was doubled linear regression at 5\% significance level. Based on the findings, it was provable that regression statistic model could applied in noticing the effect of capital structure and working capital structure on profitability through F-test. Moreover, T-test showed that capital structure negatively affected the profitability in significant manner. Lastly, working capital management was identified to be a factor that did not affect the profitability.
\end{abstract}

Keyword : Capital Structure, Debt to Equity Ratio (DER), Working Capital Management, Working Capital Turnover (WCT), Profitability, Return on Equity (ROE).

\section{PENDAHULUAN}

Salah satu isu utama penelitian di bidang financial adalah "Why firms are different or, to put it in another way, why they obtain different profitability levels" (Rumelt et al., 1994). Profitabilitas dikatakan sebagai "The primary goal of all business ventures. ” Hofstrand (2009) mengatakan bahwa tanpa profitabilitas, bisnis tidak akan bertahan dalam jangka panjang. Syamsuddin (20011:59) yang mengatakan bahwa perhatian pada profitabilitas perusahaan harus ditekankan, karena untuk dapat melangsungkan hidupnya, suatu perusahaan harus berada di dalam keadaan yang menguntungkan atau profitable. Hal ini menjadikan pengukuran profitabilitas pada saat ini, masa lalu dan memproyeksikan profitabilitas pada masa depan menjadi sangat.

Telah banyak studi empiris dan teoritis mengenai profitabilitas mengingat pentingnya untuk terus mengukur profitabilitas perusahaan. Salah satu pionir penelitian mengenai profitabilitas adalah Schmalensee (1985). Profitabilitas merupakan sesuatu yang penting bagi perusahaan, dapat dilihat dari dampaknya yang besar dari ketidakmampuan perusahaan dalam mendapatkan laba yang maksimal untuk kegiatan operasionalnya. Profitabilitas juga mempunyai arti penting dalam usaha mempertahankan kelangsungan hidupnya dalam jangka panjang, karena profitabilitas menunjukkan apakah badan usaha tersebut mempunyai prospek yang baik di masa yang akan datang. Rendahnya profitabilitas di sektor telekomunikasi ini nantinya secara tidak langsung akan mengakibatkan rendahnya GDP perkapita yang berdampak pada pertumbuhan ekonomi negara.

Profitabilitas sebuah perusahaan dapat dipengaruhi oleh berbagai hal terutama yang berkaitan dengan kegiatan manajemen yang dilaksanakan dalam perusahaan seperti pengelolaan aktiva, pengelolaan modal kerja dan sebagainya. Menurut Brigham dan Houston (2006:89), rasio profitabilitas (profitability ratio) menunjukkan pengaruh gabungan dari likuiditas, manajemen aktiva, struktur modal dan utang terhadap hasil operasi. Selain itu, margin laba bersih, perputaran total aktiva, pertumbuhan perusahaan serta ukuran perusahaan pun mampu mempengaruhi profitabilitas.

Menurut Gibson, C., (2009) terdapat tiga pengukuran yang dapat dipakai untuk melihat profitabilitas perusahaan yaitu, Return on Operation Asset (ROOA), Return on Assets (ROA), dan Return on Equity (ROE), sebagai ukuran pencapaian kepentingan pemegang saham. Penelitian ini menggunakan Return on Equity (ROE) sebagai alat ukur untuk menghitung profitabilitas, dimana penurunan profitabilitas akan menekan pencapaian laba bersih industri dan pada akhirnya menurunkan imbal hasil yang dinikmati pemegang saham. Semakin rendah ROE ini, semakin kecil tingkat keuntungan yang diperoleh pemegang saham 
perusahaan. ROE digunakan untuk mengukur tingkat keuntungan dari investasi yang telah ditanamkan oleh pemilik modal sendiri atau pemegang saham dan bila ROE bernilai negatif berarti ekuitas yang ditanam pemegang saham justru berkurang. Berdasarkan latar belakang penelitian tersebut, maka tujuan penelitian ini adalah untuk mengetahui Pengaruh Capital Structure dan Working Capital Management terhadap Profitabilitas pada PT Indosat Tbk Periode 2005-2014.

\section{KAJIAN PUSTAKA}

Manajemen keuangan perusahaan memiliki peran untuk mencari keseimbangan neraca keuangan demi menentukan struktur kekayaan didalam fungsi operasi perusahaan. Manajemen keuangan memiliki andil yang sangat besar karena memiliki peran untuk memberikan gambaran dan mengukur keberhasilan suatu perusahaan. Manajemen keuangan perusahaan perlu mengetahui perkembangan kinerja keuangan perusahaan dari waktu ke waktu terhadap apa yang telah dicapai oleh perusahaan pada masa lalu, masa sekarang dan masa yang akan datang.

Untuk mengukur kinerja keuangan suatu perusahaan, dapat menggunakan rasio keuangan yang salah satunya adalah rasio profitabilitas. Dwi Prastowo (2008) menyatakan bahwa informasi kinerja perusahaan, terutama profitabilitas diperlukan untuk menilai perubahan potensial sumber daya ekonomi yang mungkin dikendalikan di masa depan, sehingga dapat memprediksi kapasitas perusahaan dalam menghasilkan kas (dan setara kas) serta untuk merumuskan efektifitas perusahaan dalam memanfaatkan tambahan sumber daya.

Profitabilitas suatu perusahaan akan mempengaruhi kebijakan para investor atas investasi yang dilakukan. Kemampuan perusahaan untuk menghasilkan laba akan dapat menarik para investor untuk menanamkan dananya guna memperluas usahanya, sebaliknya tingkat profitabilitas yang rendah akan menyebabkan para investor menarik dananya. $A$ profitable firms can issue debt at low rates of interest since they are seen as less risky by the creditors; furthermore, profitable firms are able to generate large earnings use a lesser amount of debt capital than firms that make little profit" (Titman and Wessels, 1988; Mazur, 2007; Rajan and Zingales, 1995; Abor, 2005). Profitabilitas sebuah perusahaan juga dapat dipengaruhi oleh berbagai hal terutama yang berkaitan dengan kegiatan manajemen yang dilaksanakan dalam perusahaan seperti pengelolaan aktiva, pengelolaan modal kerja, margin laba bersih, perputaran total aktiva, struktur modal, pertumbuhan perusahaan serta ukuran perusahaan pun mampu mempengaruhi profitabilitas. (Brigham dan Houston, 2006 Riyanto, 2010)

Dalam menjalankan kegiatan operasionalnya, sebuah perusahaan selalu membutuhkan dana, dana yang dimaksud adalah modal. Untuk memenuhi kebutuhan dana tersebut, perusahaan harus mampu mencari sumber dana dengan komposisi yang menghasilkan, karena setiap investor pasti menghendaki keuntungan dari dana yang telah diinvestasikan. Menurut Bringham dan Houston (2006:18) mengemukakan bahwa dalam keputusan pendanaan dan keputusan investasi, perusahaan harus mempertimbangkan kombinasi modal yang akan ditariknya, karena modal merupakan salah satu aspek penting dalam menentukan keberlangsungan suatu perusahaan. Struktur modal perusahaan merupakan bagian dari struktur keuangan perusahaan yang mengulas cara perusahaan untuk mendapatkan dana dari manajemen keuangan. "Capital structure is one of the most puzzling issues in corporate finance literature" (Brounen \& Eichholtz, 2001). Konsep ini umumnya digambarkan sebagai kombinasi dari utang \& ekuitas yang membuat total modal perusahaan. Proporsi utang terhadap ekuitas adalah pilihan strategis manajer perusahaan dalam menentukan stuktur modal (Velnampy, 2013).

Struktur modal pada tiap perusahaan ditetapkan dengan mempertimbangkan berbagai aspek atas dasar kemungkinan akses dana, keberanian perusahaan dalam menanggung resiko, rencana strategis pemilik, serta analisis biaya dan manfaat yang diperoleh dari tiap sumber dana. Masalah struktur modal merupakan masalah penting yang dihadapi oleh seluruh perusahaan disaat perusahaan harus menetapkan pembebanan struktur keuangan dan struktur modal perusahaan secara efektif, karena baik atau buruknya struktur modal yang ditetapkan akan berpengaruh kepada struktur keuangan perusahaan yang nantinya akan berdampak pada profitabilitas perusahaan. "The capital structure of a firm is very important since it is related to the ability of the firm to meet the needs of its stakeholders."(Velnampy, 2013).

Selain struktur modal, modal kerja juga dibutuhkan oleh setiap perusahaan untuk membiayai kegiatan operasinya sehari-hari, di mana modal kerja yang telah dikeluarkan itu diharapkan akan dapat kembali lagi masuk dalam perusahaan dalam waktu yang pendek melalui hasil penjualan produksinya (Riyanto, 2010). The management of working capital is the part of the financial management responsible for the control of the gross current assets, which includes the firm's cash, account receivables and inventories (Beranek, 1966). 
Modal kerja merupakan dana yang ditanamkan ke dalam aktiva lancar untuk membiayai operasi perusahaan sehari-hari. G. Sugiyarso dan F. Winari (2006:17) mengemukakan bahwa modal kerja adalah keseluruhan dari jumlah aktiva lancar dalam kaitannya dengan hutang lancar, hal ini sejalan dengan Garcia-Teruel PJ, Martinez-Solano PM (2007) bahwa "Management of working capital generally means managing current assets and current liabilities." Tingkat efisiensi penggunaan modal kerja akan menentukan besar kecilnya tingkat keuntungan yang dihasilkan dari investasi tersebut. Untuk itu diperlukan analisis penggunaan modal kerja dengan tujuan untuk mengetahui bagaimana suatu perusahaan mengelola atau menggunakan dana yang dimilikinya (Maria, 2013). "An optimal working capital management is expected to contribute positively to the creation of firm value" (Howorth \& Weshead, 2003; Deloof, 2003; Afza \&Nazir, 2007).

\section{METODE PENELITIAN}

Objek penelitian dalam penelitian ini adalah capital structure, working capital management dan profitabilitas pada PT Indosat Tbk periode 2005-2014. Adapun yang menjadi variabel bebasnya dalam penelitian ini adalah capital structure $\left(\mathrm{X}_{1}\right)$, working capital management $\left(\mathrm{X}_{2}\right)$ dan variabel terikatnya adalah profitabilitas (Y). Untuk unit analisisnya yaitu laporan keuangan perusahaan selama sepuluh tahun berturut-turut. PT Indosat Tbk dipilih karena mengalami penurunan profitabilitas yang terlihat dari penurunan margin EBITDA dan nilai Return on Equity yang mencapai nilai negatif.

Penelitian ini berkaitan dengan data runtun waktu selama 10 tahun dari tahun 2004-2014, maka metode yang digunakan adalah time series. Jenis penelitiannya menggunakan metode deskriptif dan verifikatif. Dengan demikian, maka penelitian ini akan menghasilkan gambaran mengenai capital structure, working capital management dan profitabilitas pada PT Indosat Tbk dan diuji mengenai seberapa besar pengaruh capital structure dan working capital management terhadap profitabilitas. Dalam penelitian ini menggunakan metode explanatory research yang bertujuan untuk menguji hipotesis antara variabel yang satu dengan variabel yang lain.

\section{HASIL PENELITIAN \& PEMBAHASAN}

Pengujian dalam penelitian ini menggunakan Uji $F$ dengan tujuan untuk mengetahui pengaruh-pengaruh variabelvariabel independent, yaitu capital structure $\left(\mathrm{X}_{1}\right)$ dan working capital management $\left(\mathrm{X}_{2}\right)$ terhadap variabel dependent, yaitu Profitabilitas
(Y) dengan menggunakan uji keberartian regresi, tabel berikut akan menunjukan hasil Uji F dalam penelitian ini,

\section{TABEL HASIL PENGUJIAN UJI F} ANOVA

\begin{tabular}{ccccccc}
\hline Model & & $\begin{array}{c}\text { Sum of } \\
\text { Squares }\end{array}$ & Df & $\begin{array}{c}\text { Mean } \\
\text { Square }\end{array}$ & F & Sig. \\
\hline 1 & Regression & 697.356 & 2 & 348.678 & 8.887 & $.012^{\mathrm{b}}$ \\
& Residual & 274.648 & 7 & 39.235 & & \\
& Total & 972.004 & 9 & & & \\
\hline
\end{tabular}

a. Dependent Variable: ROE

b. Predictors: (Constant), WCT, DER

Sumber : Hasil pengolahan data 2016

Pada tabel di atas menunjukan bahwa hasil $\mathrm{F}_{\text {hitung }}$ pada penelitian ini adalah sebesar 8.887, sedangkan berdasarkan tabel $\mathrm{F}$, besaran $\mathrm{F}_{\text {tabel }}$ adalah 4.46 maka dengan begitu nilai $F_{\text {hitung }}$ lebih besar dari $\mathrm{F}_{\text {tabel }}$ atau 8.887>4.46 dengan demikian menunjukan bahwa $\mathrm{H}_{\mathrm{o}}$ ditolak. Nilai signifikansi dari $F_{\text {hitung }}$ adalah 0.012 yang menunjukan bahwa nilai tersebut lebih kecil dari taraf nyata $5 \%$ atau $0.012<0.05$. Hal ini membuktikan bahwa model regresi dapat digunakan untuk melihat pengaruh capital structure dan working capital management terhadap profitabilitas.

Model regresi yang digunakan dalam penelitian ini adalah regresi linier berganda yang bertujuan untuk meramalkan naik turunnya variabel dependent, dengan dua variabel independent sebagai faktor predictor yang dimanipulasi. Tabel di bawah ini akan menunjukan hasil uji regresi linear berganda dengan penggunaan persamaan regresi berganda $\left(\mathrm{Y}=\mathrm{b}_{0}+\mathrm{b}_{1} \mathrm{X}_{1}+\mathrm{b}_{2} \mathrm{X}_{2}\right)$.

\section{TABEL UJI REGRESI LINEAR} BERGANDA

\begin{tabular}{|c|c|c|c|c|c|}
\hline \multirow[b]{2}{*}{ Model } & \multicolumn{2}{|c|}{$\begin{array}{l}\text { Unstandardized } \\
\text { Coefficients }\end{array}$} & $\begin{array}{c}\text { Standardized } \\
\text { Coefficients }\end{array}$ & \multirow[b]{2}{*}{$\mathrm{T}$} & \multirow[b]{2}{*}{ Sig. } \\
\hline & $\mathrm{B}$ & $\begin{array}{l}\text { Std. } \\
\text { Error }\end{array}$ & Beta & & \\
\hline 1 (Constant) & 33.317 & 8.927 & & 3.732 & .007 \\
\hline DER & 16.798 & 4.341 & -.781 & -3.869 & .006 \\
\hline WCT & -.349 & .272 & -.259 & -1.283 & .240 \\
\hline
\end{tabular}

Sumber : Hasil pengolahan data 2016

Pada tabel di atas dapat dilihat dalam kolom B nilai konstanta dan nilai koefisien regresi linear berganda untuk masing-masing variabel independent. Berdasarkan nilai-nilai di atas dapat ditentukan model regresi linear berganda yang dinyatakan dalam bentuk persamaan, sebagai berikut:

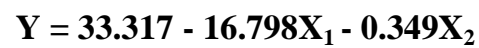

Berdasarkan persamaan tersebut dapat diketahui bahwa :

a. Nilai konstanta 33.317, ini berarti bahwa jika capital structure dan working capital management tidak 
mengalami perubahan maka nilai profitabilitas sebesar 33.317.

b. Nilai koefisien regresi capital structure $\left(\mathrm{X}_{1}\right)$

Nilai koefisien capital structure sebesar -16.798, nilai ini menunjukan bahwa setiap peningkatan capital structure sebesar 1.00 kali maka akan menyebabkan penurunan profitabilitas sebesar $-16.798 \%$.

c. Nilai koefisien regresi working capital management $\left(\mathrm{X}_{2}\right)$

Nilai koefisien working capital management sebesar -0.349 , nilai ini menunjukan bahwa setiap peningkatan working capital management sebesar 1.00 kali maka akan menyebabkan penurunan profitabilitas sebesar $0.349 \%$.

Sedangkan untuk menguji keberartian koefesien regresi dilakukan melalui uji t dengan cara membandingkan antara $t_{\text {hitung }}$ dengan $t_{\text {tabel }}$ dari koefisien regresi tiap variabel independen secara statistik. Tabel berikut merupakan hasil Uji T untuk mengetahui pengaruh antara capital structure dan working capital management terhadap profitabilitas,

\section{TABEL HASIL PENGUJIAN UJI t}

\begin{tabular}{|c|c|c|c|c|c|}
\hline \multirow[b]{2}{*}{ Model } & \multicolumn{2}{|c|}{$\begin{array}{l}\text { Unstandardized } \\
\text { Coefficients }\end{array}$} & \multicolumn{3}{|l|}{$\begin{array}{l}\text { Standardized } \\
\text { Coefficients }\end{array}$} \\
\hline & B & $\begin{array}{l}\text { Std. } \\
\text { Error }\end{array}$ & Beta & $\mathrm{t}$ & Sig. \\
\hline 1 (Constant) & 33.317 & 8.927 & & 3.732 & .007 \\
\hline DER & $\begin{array}{r}- \\
16.798\end{array}$ & 4.341 & -.781 & -3.869 & .006 \\
\hline WCT & -.349 & .272 & -.259 & -1.283 & . 240 \\
\hline
\end{tabular}

Sumber : Hasil pengolahan data 2016

Tabel di atas merupakan hasil perhitungan uji yang membuktikan bahwa :

a. Keberartian koefisien regresi Capital structure terhadap profitabilitas

Hasil uji t menunjukan bahwa nilai $t_{\text {hitung }}$ sebesar 3.869. Berdasarkan nilai $t_{\text {tabel }}$, besaran $t_{\text {tabel }}$ dalam penelitian ini adalah 2.364 dengan demikian maka $t_{\text {hitung }}>t_{\text {tabel }}$ atau 3.869> 2.364. Adapun nilai signifikansi dari $t_{\text {hitung }}$ adalah 0.006 , yang berarti nilai tersebut lebih kecil dari taraf nyata $5 \%$, atau $0.006<0.05$ dengan demikian dapat dibuktikan bahwa $\mathrm{H}_{01}$ ditolak yang berarti capital structure berpengaruh terhadap profitabilitas. Nilai $\mathrm{t}$ negatif menunjukan bahwa capital structure memiliki hubungan yang berlawanan arah dengan profitabilitas.

b. Keberartian koefisien regresi working capital management terhadap profitabilitas

Hasil uji t menunjukan bahwa nilai $t_{\text {hitung }}$ sebesar 1.283. Berdasarkan nilai $t_{\text {tabel}}$, besaran $t_{\text {tabel }}$ dalam penelitian ini adalah 2.364 dengan demikian maka $t_{\text {hitung }}$ lebih kecil dari $t_{\text {tabel }}$ atau $1.283<2.364$. Adapun nilai signifikansi dari $t_{\text {hitung }}$ adalah 0.240 , yang berarti nilai tersebut lebih besar dari taraf nyata $5 \%$, atau 0.240> 0.05 dengan demikian dapat dibuktikan bahwa $\mathrm{H}_{02}$ diterima yang berarti working capital management tidak berpengaruh terhadap profitabilitas. Nilai $t$ negatif menunjukan bahwa working capital management memiliki hubungan yang berlawanan arah dengan profitabilitas.

Hubungan antara struktur modal dan profitabilitas itu sendiri telah menjadi subjek dari tonggak yang luar biasa selama beberapa dekade terakhir. Penelitian mengenai efek dari struktur modal terhadap profitabilitas akan membantu kita untuk mengetahui potensi masalah dalam kinerja dan struktur modal. Masalah struktur modal merupakan masalah penting yang dihadapi oleh seluruh perusahaan disaat perusahaan harus menetapkan pembebanan struktur keuangan dan struktur modal perusahaan secara efektif, karena baik atau buruknya struktur modal kerja yang ditetapkan akan berpengaruh kepada struktur keuangan perusahaan.

Seperti yang dikemukakan oleh Velnampy (2013) bahwa "The capital structure of a firm is very important since it is related to the ability of the firm to meet the needs of its stakeholders." Untuk pengaruh negatif dari capital structure terhadap profitabilitas didukung oleh beberapa penelitian, diantaranya Mutaju Isaack Marobhe (2014:92) mengungkapkan "Profitability and it was found that Capital structure has significant negatif relationghip with ROA but weak relationship with ROE dan EPS." Khalid Ashraf (2013:189) "Debt to Equity ratio is negatifly correlated to profitability ratios which imply that if the debt content is increased aggressively it will adversely impact the profitability."

Sedangkan tidak berpengaruhnya working capital management terhadap profitabilitas, didukung oleh pendapat Vedavinayagam Gangnesan (2007) "Working capital managaement is negatifly related to the profitability, it is not significantly impacting the profitability of firms in telecommunication equipment industri." Modal kerja yang digunakan dengan efektif dan efisien akan dapat memaksimalkan perolehan laba perusahaan sehingga profitabilitas pun akan naik, hal ini dikarenakan semakin cepat perputaran modal kerja akan semakin efisien penggunaan modal kerja sehingga pengelolaan modal kerja tidak berlebihan, yang pada akhirnya profitabilitaspun meningkat. 


\section{KESIMPULAN}

Berdasarkan uraian teori dan hasil penelitian yang telah dilakukan dengan menggunakan analisis deskripsi dan verifikatif serta uji regresi liniear berganda antara capital structure dan working capital management terhadap profitabilitas pada PT Indosat Tbk periode 2005-2014, dapat ditarik kesimpulan bahwa hasil uji t menunjukan bahwa capital structure berpengaruh secara negatif terhadap profitabilitas, dimana kenaikan pada capital structure maka akan berpengaruh terhadap penurunan profitabilitas. sedangkan dalam working capital management, tidak terdapat pengaruh terhadap profitabilitas, dimana jika terjadi perubahan pada working capital management tidak akan berpengaruh pada naik atau turunnya profitabilitas perusahaan.

\section{DAFTAR PUSTAKA}

Abor, J.(2005). The effect of Capital structure on profitability: empirical analysis of listed firms in Ghana. Journal of Risk Finance, 6(5), 438-445

Ashraf, Khalid., Khursheed Ali \& Mouh-iDin.(2013). Impact Of Capital structure On Profitability Of Listed Companies. The USV Annals of Economics and Public Administration Volume 13, Issue 1(17)

Beranek W.(1966). Working capital management. 1st edition. Wads-worth. California

Brigham, Eugene F and Joel F.Houston.(2006). Dasar-Dasar Manajemen Keuangan, alih bahasa Ali Akbar Yulianto, Buku satu, Edisi sepuluh, PT. Salemba Empat, Jakarta

Brounen, Dirk and Eichholtz, Piet M.A.(2001). Capital structure Theory: Evidence from European Property Companies' Capital Offerings. American Real Estate and Urban Economics Association. Vol 29 Issue 4, 615-632.

C.Howorth and P. Westhead.(2003). The focus of working capital management in $U K$ small firms. Management Accounting Research, vol. 14, no. 2, pp. 94-111

Deloof, M.,(2003). Does working capital management affect profitability of Belgian firms?. Journal of Business Finance \& Accounting. Vol. 30 No. 3-4, pp. 573587.

Gibson, C.(2009). Financial Reporting \& Analysis - Using Financial Accounting Information. Mason: South Western Cengage Learning.

Hofstrand, Don. (2009). Understanding Profitability. File C3-24, Iowa State University

Nazir, M., \& Afza, T.(2009). Impact of Aggressive Working Capital Management Policy on Firms' Profitability. The IUP
Journal of Applied Finance , 25 (8), 1930 .

Maria.(2013). Analisis Penggunaan Modal Kerja Terhadap Profitabilitas Pada PT Tunas Jaya Gemilang Palembang. Jurnal Ilmiah. Vol V No 11.

Mazur K. (2007). The Determinants of Capital structure Choice: Evidence from Polish Companies. Int. Adv. Econ. Res., 13, 4, 495-514.

Mutaju Isaack Marobhe.(2014). The Influence of Capital Structure on the Performance of Manufacturing Companies : Empirical evidence from listed companies in East Africa. Tanzania

P. J. Garcia-Teruel and P. MartínezSolono.(2007).Effects of Working capital management on SME Profitability. International Journal of Managerial Finance, vol. 3, no. 2, pp. 174-177.

Prastowo, Dwi.(2008). Analisis Laporan Keuangan. YKPN, Yogyakarta.

Rajan, R.G., \& Zingales, L.(1995). What Do We Know about Capital Structure? Some Evidence from International Data. Journal of Finance, 50, 1421-1460.

Riyanto, Bambang. (2010). Dasar-dasar Pembelanjaan Perusahaan, Edisi 4. BPFE, Yogyakarta.

Rumelt, R.P., Schendel, D., and Teece, D. I (1991). Strategic management and economics. Strategic Management Journal, 12 (Winter), 5-30. S.

Schmalensee, Richard,. (1985). Do Market Differ Much?. The American Economic Review, Vol. 75, No. 3, 341-351

Sugiyarso. G dan F Winarni.(2006). Manajemen Keuangan (Pemahaman Laporan keuangan, Pengelolaan Aktiva, Kewajiban dan Modal serta Pengukuran Kinerja Perusahaan. Media Pressindo, Yogyakarta.

Syamsuddin, Lukman.(2011). Manajemen Keuangan Perusahaan: Konsep, Aplikasi dalam Perencanaan, Pengawasan dan Pengambilan Keputusan. PT. Raja Grafindo Persada, Jakarta

Titman, S. and Roberto W.,(1988).The Determinants of Capital Structure.Journal of Finance, 43(1), 1-19

Vedavinayagam Ganesan.(2007). An Analysis of Working capital management Efficiency in Telecommunication Equipment Industri. Rivier Academic Journal. Vol 3 Num 2.

Velnampy T,. Kajananthan R.(2013).Cash Position and Profitability of Telecommunication Sector in Srilanka. Greener Journal of Social Sciences ISSN: 2276-7800 Vol. 3 (6), pp. 324-333 